\title{
From the Traumas of the Caribbean to a Revival of Resistant Literature: A West Indian Discourse
}

\author{
Nayera Mohammed Hassan ${ }^{1}$ \\ Jouf University-Saudia Arabia and Minia University- Egypt
}

\begin{abstract}
This paper presents the history of the Caribbean peoples, their traumas, migrations, and their endeavors to recreate a collective cultural identity and go beyond their de-homing status. It focuses on the emergence of a resistant Caribbean literature that has helped in raising the voice of the Caribbean peoples. It conveys their yearnings, anxieties, and confusions, suggesting both geographic displacement and psychological dislocation. Within a post-colonial world that has remained dependent and underdeveloped, migration to Europe became an inevitable process. West Indian writers joined these successive waves of arriving migrants initiating a literature of exile. Later, several exiled post-colonial writers rejected the status of exile in favor of that of a migrant. This shift to the immigrant genre resulted in the writer's acceptance of his or her duality and ambivalence. In this study, the focus of research is to be narrowed down to Anglo-Caribbean writers and those of British West Indies. Hence, this approach to history adopts a descriptive documentary method, based on decisive incidents in the lives of these diasporic people. It relies, as well, on the opinions of theoreticians, writers, and scholars. The findings of this study indicated that Caribbean resistance, in the face of racism and marginalization, is an ongoing process in our contemporary world. They also showed an apparent revival of Caribbean writing, which scholars expect to play a role in enriching and adding to the British and American literatures.
\end{abstract}

Keywords: Caribbean, diaspora, literature, migration, post-colonial, resistance.

\section{Introduction}

The problem of belonging and searching for home is one of the characteristics of our modern mobile world. So, the Caribbean complex history of violent up rootedness makes it a suitable field for examining such a problem. The Caribbean peoples have been stripped of their original histories, cultures, languages and religions, driven to alien environments where they have created, through miscegenation, racially mixed people. Several different African peoples were brought to the West Indies as slaves. Moreover, the shortage of workers, after emancipation, led to the introduction of the indentured laborers from many countries who were also stranded in the Caribbean. Although most of the Caribbean islands have gained independence, they are still subject to their former European owners. In fact, the West Indies have become a sort of microcosm of the entire world, containing people originating from every continent. These ethnic groups, who were thrown together by enforced enslavement, violent rupture, and fragmentation, found themselves with no way back home.

Although this study deals specifically with the Caribbean, it has broader implications. The study addresses the young generations all over the world, particularly whites, to get them

\footnotetext{
${ }^{1}$ E-mail: mailto:nayerahassan@yahoo.com
} 
to be more aware of the Caribbean traumas and be able to grasp the impact of exploitation and racism on the oppressed people. Also, the hard experience of the Caribbeans is presented to actuate the oppressed nations everywhere, and encourage them to pass steadfast over the road of struggle and resistance. The target of the study is to bring into focus the birth, the development, revival, and global resonance of a Caribbean literature through two generations.

As a chronicle of important Caribbean happenings, this literary study adopts a descriptive documentary method in drawing a whole picture of the Caribbean world, one that epitomizes the human suffering in its deepest sense. The first part of the study presents a review of previous research into diasporas, followed by a detailed survey of the Caribbean dilemmas and the migration of the English speaking Caribbeans to England. The second part highlights the various literary responses of the first and second generations of Anglo-Caribbean writers to the realities of their region. The third part is dedicated to the findings which are related to Caribbean issues and literature. The paper ends with suggestions for further research.

\section{A Review of Previous Research into Diasporas}

The most essential characteristic of the West Indies is its diasporic dimension. Hall (2001) indicated that "everybody in the Caribbean comes from somewhere else....their true cultures, the places they really come from, the traditions that really formed them are somewhere else. The Caribbean is....the purest diaspora" (pp. 27-28). The Dictionary of Global Culture says that "Diaspora" with capital D, in its original sense, refers to the process by which the Jews were exiled from their homelands. Historically, the Diaspora had undergone different phases, the first significant one occurring in $586 \mathrm{BCE}$ when the Babylonians conquered Judah, leading to the enslavement of the Jews. The largest Diaspora, which occurred during the first century BCE, and lasted for 1800 years, led to the displacement of five million Jews. Diaspora is often associated with Zionism, which is the belief in the Jews' legitimate claim to a homeland (Palestine) (Appiah, 1998). The Oxford English Dictionary traces the word "Diaspora" back to its appearance in the Old Testament, referring to God's intentions for the people of Israel to be dispersed across the world. Safran (1991) claimed that diasporas "retain....a vision of myth about their original homeland and regard their ancestral homeland as their true ideal home to which they will return someday" (p. 90).

However, this is not the case with the Caribbean diaspora, as referred to by Hall. Caribbean people are disinterested in returning to India or Africa, or any other original homeland, due to the violent rupture and separation from their place of origin through slavery and indentured labor. What Hall refers to is a Caribbean diaspora that can never hope for a return. He means diaspora created through heterogeneity, diversity, and hybridity. Being Caribbean or West Indian means that one has been cut off from his or her original home. The absence of home and the feeling of homelessness are the hallmark of West Indian identity.

Ledent (2017) indicated how "the parallel between the Jewish and the African diasporas is a traditional one in Black America. It was established in the days of slavery; Rastafarianism, a Black religious movement discovered in the Old Testament another enslaved people, the Jews"(p. 201). The movement regarded Jamaicans as prisoners of Babylon-the white colonial system from which they will escape to reach the promised land that is Ethiopia" (p. 201).

Ledent noted that, in the English-speaking Caribbean, creative writers were inspired by the similarity in the experiences of exclusion, oppression, and extermination between the Jewish and the Africa-Caribbean diasporas. This appears in much of Wilson Harris' prose, particularly his novel Jonestown (1996). There also is John Hearne's novel Land of the Living (1961), in which a Jewish refugee and an African leader of a church, linked to a back-to-Africa group, each can be viewed as representing their own community. A similar interaction between Blacks and Jews is suggested in Paule Marshall's The Chosen Place, the Timeless People (1969), a novel bringing together Afro-Caribbean characters and a white Jewish one. The latter 
sees that the Jewish heritage of suffering passed on by his mother became the means by which he understood the suffering of others. Also, the parallel can be found in Derek Walcott's (2007) poetry in his piece," "A Far Cry from Africa," where the poet comments on a rebellion in Kenya in the 1960s and speaks of so-called "savages, expendable as Jews" (p. 202).

This compassion with the Jewish experience seems to be more apparent in the work of the younger generation of Anglophone Caribbean writers who live diasporic lives in England and the United States. Several of them tackle the analogy between the African and Jewish conditions through references to the Holocaust. Ledent (2017) showed, through a few selected examples, that contemporary Caribbean writers' portrayal of Black and Jewish suffering, "is part of their open-minded attempt to explore their own sense of otherness ..... and to achieve a multifaceted vision of the world"(p. 203).

In David Dabydeen's novel, A Harlot's Progress (1999), set in eighteenth-century London, a young servant of African descent meets a Jewish doctor with whom he feels a kind of solidarity, and a clear connection is established between these two outsiders. The JamaicanAmerican, Michelle Cliff, is another Caribbean author, who refers to "Jewishness and Nazism" in her novel Abeng (1984), her first collection of prose poems, The Land of Look Behind (1985), and in her short story, A Woman Who Plays Trumpet Is Deported. The history of the Jewish people had a profound effect on Caryl Phillips as well. Two of C. Phillips's novels are relevant here: Higher Ground (1989) and The Nature of Blood (1997). He shows similarities between the African and Jewish experience and "tries to set up a dialogue among the victims of exclusion" (Ledent, 2017, p.209).

Ledent et al. (2018) conveyed the idea of how West Indian writers depicted, as well, the opposite made-up picture of the Caribbeans, which is inevitably a colonial creation saying the Caribbean "has, throughout its history, been represented as an exotic, odd place where "natives believe and act in strange non-Western ways"(p. 1).Such mental status is portrayed in narratives set during colonization and decolonization periods. In fact, the legacy of enslavement brought forth such traumas. Ledent et al. (2018) mentioned several allusions to insanity. They referred to Jean Rhys's, Wide Sargasso Sea (1966), as a work that "has become iconic" in any discussions of literary works handling mental aberration (p. 2). In depicting this mental state, the authors claim that Caribbean writers, including the young generation, avoid seeing the Caribbean as a "deranged space" to regard it as "one that accommodates altered states of consciousness"(p. 2). The fact that writers today are still bandaging these psychic wounds in the twenty-first century is a cause for concern. Those wounds were likely inflicted by the continuing displacement, violence, and the increasing crises of people longing for acceptance. Despite the negative depiction of these psychic consequences, the authors emphasized that the "temptation to pathologize the Caribbean as a site of derangement must be resisted" (Ledent et al., 2018, p. 5).

Away from these historical diasporas and their impact on Caribbean literature, Ugurlu (2014) claimed that diaspora has become a popular area of study in social science and that it has gained a different meaning in today's world. Based on critical views, he mentioned the term diaspora as defining any group of immigrants related by their collective identity in the host country. Accordingly, there are the Palestinian, Egyptian, Asian diasporas. These may have social organizations that pursue their issues and examine their problems (Addai-Mununkum, 2019; Soyer, 2019).

\section{A Survey of Caribbean History}

The Caribbean is a region of the Americas consisting of the Caribbean Sea, its islands and the surrounding coasts. These islands, first discovered by Columbus and other early navigators, are known as West Indies. They usually are thought of as a sub-region of North 
America. The West Indies is an archipelago that is a sea with many islands in it. This archipelago curves 2.500 miles from Florida in the North to Venezuela in the south, facing Central America on the West, with the East separating the Atlantic Ocean from the Caribbean Sea. Roberts (2007) said that Arawaks, gentle Indian tribesmen, were the original inhabitants of the West Indies, but were driven out by the Caribs, who were fierce warriors. For 250 years, the Caribs prevented any Europeans from settling on the islands. At some point, most of the West Indies became colonies of European nations. Thus, there were Spanish, French, British, Danish, Swedish, and Portuguese West Indies.

The worst features of colonialism are combined in this region. The indigenous peoples, namely the American Indians who lived in the region before Columbus' discovery, proved to be unsuitable for slave labor in the newly formed plantations. So, the Native Americans were wholly and brutally destroyed, their homes were confiscated and robbed, and their oral traditions disappeared as they died out during Spanish colonization in the $16^{\text {th }}$ century. The search for cultural identity always imposes a search for origin. However, it is impossible to find an origin for the Caribbean because those indigenous peoples no longer exist (Roberts, 2007, p. 7).

People were brought entirely against their will to the Caribbean region. With European colonization, came the greater violence of slavery, and several different African peoples were brought to the West Indies as slaves. They were whipped and tortured to force them to serve the plantation economy. They were isolated from their common language group and sold in mixed lots as a deliberate means of limiting the possibilities of rebellion. Language suppression continued, and the result was that, within two or three generations, the only language available to the Africans in this alien land was the European language of the master. Those Africans did not possess a written tradition of their own, nor were they allowed to develop one.

Lowenthal (1978) claimed that sugar as the main crop of the rich people was "in enormous demand and was well suited to West Indian soils and climate" (p. 27). This did not mean that sugar displaced other crops such as cotton, coffee, and cacao, which were grown for export. However, the planters preferred sugar, and, by the end of the eighteenth century, sugar plantations, built on large-scale African slavery, had spread to every Caribbean land that the European enterprise could capture and colonize. Field hands were needed in large numbers in the sugar plantations. That need could be filled by cheap African slaves who were accustomed to the harsh conditions of labor in tropical areas. Hoetink (1982) explained,

Slavery as an economic system, depended, as far as the character
of the dealings between master and slave are concerned, to a great
extent on the relations of production. On the large plantations
producing for a world market, the treatment of slaves was, by and
large, more severely regimented and cruel than in the pastoral
livestock enterprises. Moreover, the lot of the field slaves was
generally sadder than that of slave artisans [andworkmen]. (p. 182)

This means that the more valuable the product, the crueler the treatment of slaves must be to force them to work harder. Hoetink's words imply that colonization is a policy by which a nation extends its power and control over other nations. It is an inhuman act whose goal is not a benevolent desire to wipe out ignorance, disease, and backwardness among the natives. On the contrary, it aims at domination, submission, and dehumanization.

Cesaire (2000) indicated that the "colonial activity is based on contempt for the native and justified by that contempt . . . consequently the colonizer gets into the habit of seeing the other man as an animal [and] accustoms himself to treating him like an animal" (p. 41).This face-to-face confrontation between the colonizer and the colonized includes force, brutality, and conflict in a way that turns the colonizer into an instrument of humiliation and oppression. 
When slavery was abolished in 1834, the plantations suffered an economic decline, and the conditions of former slaves were not improved, and slave history was not erased. For most slaves, emancipation was partial and incomplete. The freed slaves remained in economic bondage and political subjugation. Full emancipation came slowly, and with it, racial tensions. The Black ex-slaves were still treated in a humiliating manner by the new generations of white ex-masters. Whites considered themselves the only West Indian inhabitants. Even those who slept with women ex-slaves viewed them more as property than as persons. However, whether slaves or ex-slaves, the colonized people were not the only ones who felt alienated. Their former masters could not overcome the feeling of estrangement as they tried to preserve their identity in such an alien land.

After Emancipation, the shortage of labor led to the introduction of the indentured laborers from Ireland, England, Scotland, China, India, and many other countries. Those laborers were stranded in the Caribbean, but they were not paid, rewarded or secured for their hard back-breaking work. Hence, with the genocide and destruction of the Arawaks, Caribs, and Amerindians and through slavery and indentured labor, West Indian history is made of ruptures. Differences between the various islands exist, but they are united by their colonial and imperial history.

Because of the dislocations that colonization and slavery caused, the cultural identity of the Caribbean is problematic. All ethnic and racial groups in the Caribbean came from other home countries; they are people intermingling with one another, producing an inordinate amount of ethnic and cultural diversity. Culture clash and miscegenation shaped the texture of the Caribbean from the early days of slavery. Most populations were separated from their own cultures and were inserted into the cultures of the colonizers. They were victims of the worst diaspora in the world, which means that they were not only displaced from their country but their culture, language, history and personal and societal experiences. They experienced a sense of uprootedness and unbelonging. Under such circumstances, it was impossible to find home in the Caribbean.

Carew (1978) summed up the story of this displacement, saying, "The history of our exile is a dismal one of ethnocide, slavery, indentured labor, racism, colonialism and more recently neo-colonialism. Everywhere that we touch the earth in this hemisphere and seek to establish roots, the roots are bound to invade the graves of the innocent dead" (p. 460). His words imply that the first obstacle to self-definition and finding home is the uncontrolled history of dislocation and the ghosts of the ancestors, the victims of this history. He stresses the difficulty of seeking home in a ground that still bears the marks of a traumatic past.

To ensure economic and political domination, the colonizing power tried to control the cultural environment and wipe out the cultural identity of those people to dictate their values and their image of self. The colonizing power entrenched itself in the minds of the Caribbean populations as a sort of mental colonization. There was an intensification of racial difference based on Western superiority and colored, or colonial, inferiority. West Indians had no choice but to imagine themselves as others, that is, to adopt the colonialists' definition of their selves. Hence, the education system imposed on the people of the Caribbean became a powerful way to deny the Blacks a history, a culture, and a sense of identity.

Notably, West Indians' circumstances differ from those of other colonies; the Caribbeans have faced the difficulties of co-habitation between different races and the identity crisis caused by an uprooting process. Juneja (1996) quoted the words of Eric Williams, the first Prime Minister of Trinidad. Williams says, "All these other victims of imperialism have had decisive advantages over the West Indies. They had a language of their own, a culture of their own....as in India, a family structure of their own as in Ghana, a sense of values of their own which they could oppose to Western Imperialism. We in the West Indies have nothing of our own" (pp. 3-4). He stressed the difficulties of forming a society due to the imperial history 
of displacement and deprivation and showed how cultural alienation predominates in the West Indies.

In this context, it might be said that, because the West Indians have nothing of their own, they have been forced to use the broken fragments of different traditions and cultures at their disposal in an attempt to create a collective identity. This blending of cultural fragments generates more positive concepts, such as creolization, syncretism, or métissage. Creolization implies a sense of cultural interaction not only among all traditions of the West Indies but also between these traditions and some Western aspects. It is a mixture of cultures of different origins. Besides, the English language as a shared legacy of British colonialism and the imposition of this language on colonized peoples has led to a type of English considered standard Creole or patois. Patois derives from old French and is used in the English language to refer to a geographical dialect that differs from English as a language of power. Syncretism also is an attempted union or reconciliation of diverse or opposite doctrines and beliefs. Finally, métissage suggests the existence of people of mixed descent all over the Caribbean. In brief, it is a cultural recreation based on the different traditions, the different races, and the intermingling process present on the islands. Hence, it is not that West Indians have nothing. Instead, the only things that have survived from their difficult history are fragmentary and incomplete. So, they must find their strength in the combination of these fragments and the blending of these different traditions.

Emphasizing the difficulty of this necessary recreation of a Caribbean cultural community, Juneja (1996) said, "Personal and cultural identities have had to be negotiated in an arena that offers either the taint of replication and mimicry of the colonial culture or a seeming cultural vacuum" (p. 7). His words mean that West Indians must find a balance between these two dangerous extremes; their true identity lies along two edges. They must overcome both the problem of the absence of a particular Caribbean culture and that of being mere mimic nations, subordinated to the colonists whom they imitate. They must reassemble the pieces of broken traditions, including the colonial culture, without impairing or damaging any of these traditions.

This understanding of cultural identity as a construction also is underlined by Hall (1990) and Akinsola (2020), who claimed that cultural identity is a matter of "becoming" as well as of "being." Hall saw that West Indian identity is continuously changing because "it is not something which already exists, transcending place, time, history and culture" (p. 223). His words stressed the idea that West Indian identity is in the process of reconstruction, at the stage of becoming. It has not yet been well established but is moving forward. Hall warns against the absence of a specific Caribbean identity, which is a destructive effect of colonialism. He said, "This inner expropriation of cultural identity crippled and deformed, if its silences are not resisted, they produce, in Fanon vivid phrase, individuals without an anchor, without horizon, colorless, stateless, rootless ... a race of angels " (p. 223). The imperial history is not only the cause of traumatic displacements, but also of the deprivation of cultural identity. If West Indians did not attempt to reconstruct their cultural identity, they would never stand on a solid footing and would remain rootless and insignificant.

Although most of the Caribbean islands have gained independence, they were subject to their former European owners. Within a post-colonial world that has remained dependent and underdeveloped, migration becomes an inevitable process. Colonialism and imperialism, indeed, account for the migration of people of color into the industrialized countries. Since the 1940s, large numbers of Caribbean people and refugees have left their homelands for economic, political, or professional reasons, creating large diasporas of people who seek a place, a voice, and a sense of belonging in a new country.

After fighting on the British side in World War II, the Caribbeans, along with other people from Asia and Africa, were invited to work in the Mother country. These migrants became part of a new working class in Britain, and, as they struggled to make the United 
Kingdom their home, they faced new forms of racism, always troubled and abused (John, 2005). In this way, the Caribbean people were twice diasporized. Despite their attempts to accommodate themselves to the new environments, they remained marginalized and treated as others. Once again, they lived in displacement, isolation, and cultural alienation. Thus, the West Indians' fate is to migrate, to leave home for a new country, and to abandon a culture for another.

\section{Anglo-Caribbean Writers Through Two Generations}

With these migrations emerged the corresponding literature of exile. This literature focused on the idea of place and displacement, and the life and experiences of the Caribbean community and the other communities living on the border zone of two cultures. Writers in exile share a special concern with questions of identity, ethnicity, and language that rise out of the Caribbean historical experience. They tend to focus on what was left behind through their fiction.

However, the conditions of cultural production, material, and intellectual resources, book production, publishing, audience, and critical reception are greatly different in "First" and "Third" world areas. These conditions, while reflecting the opposition between the home and host countries, necessitated that post-colonial writers enter Western cultural centers precisely to make their cultural productions possible. Brodsky (1991) remarked that a search for "home" is often a search for a negotiated physical and mental space that brings a writer closer to the seat of ideals that inspired him or her all along. Exiled writers have gone to England or France in search of a better life and publication opportunities. They have come into the West as products of a colonial educational system and Western literary tradition. So, their approach to European centers asserts their own partly European cultural heritage. One might say that it is a sort of mental colonization perpetuated in a colonizer's language education and cultural values. George (1999) stated that, although the form of some of the fiction in English by writers from the colonies relies heavily on English literary traditions, this does not extend to the contents of the fiction. To raise his or her voice, a formerly colonized writer changes the contents of the English novel, even if the utterances are in the "master's voice" (p. 5).

Gikandi (1992) justified the need for a Caribbean cultural production. He said, "since colonial modernity denied the Caribbean an 'other history' --a version of events distinct from the conventional European narrative in which the islands exist solely as a project of the conqueror's expansionism-- West Indian writing would come to function as a forced entry (into history) through the iron curtain of colonial culture" (pp. 6-7). Gikandi meant that Caribbean writers have produced numerous responses to the history of displacement and migration. They have constructed an original and specific literature resulting from their desire to create a new Caribbean narrative different from that of the imperial conquest and expansion, that besets all the Caribbean region. Hence, Caribbean literature is a counter discourse fighting the conqueror's assumptions. The writers who witnessed the birth of this literature of exile are referred to as the first-generation of Caribbean writers. Carew (1978) summarized the situation of this generation saying,

The Caribbean writer.... is a creature balanced between exile abroad and homelessness at home, between the people on the one hand and the Creole and the colonizer on the other. Exile can be voluntary or it can be imposed by stress of circumstances; it can be a punishment or a pleasure. The exile can leave home for a short time or he can be expelled forever. The colonizing zeal of the European, made indigenous peoples, exiles in their own countries . 


\section{.. The Caribbean writer, by going abroad, is in fact searching for an end to exile. (p. 453)}

The words underline the writer's difficulty of feeling at home in a country built on oppression and the problem of feeling like an exile in one's own country. Thus, the exiled condition of Caribbean writers should help them to discover their home and end their expatriation.

Mardorossian (2002) stated that since the 1970s, some post-colonial writers have "reconfigured" their identity by replacing the status of exile to that of a migrant. Writers might still be undeniably living "in exile" from their native land, but the shift from exile to migrant literature "challenges literary criticism's traditional reliance on that experience as the basis of explanation in literary analysis" (pp. 15-16). This shift to the immigrant genre results in the writers' acceptance of their duality and ambivalence. They live in a mode of belonging and notbelonging, and their collective voice tells them how to feel a stranger and yet at home, to live simultaneously inside and outside their immediate situation.

Immigrant fictions are concerned with the experience of immigration to Western nations and the recent waves of migrants, from Anglophone, Hispanophone, Francophone territories, and from others once colonized by different imperial powers. Mardorossian (2002) claimed that migrant art offers a transnational, cosmopolitan, multilingual, and hybrid map that re-draws boundaries by building bridges between Third and First worlds. Naficy (1993), as well, highlighted the point, saying that "this new migrancy is about ambivalence, resistance....doubling, and even subversion of the cultural codes of both the home and host societies" (p. 37). While the first generation of exiled writers focus on the mediated notions of identity and belonging, desperately seeking a coherent sense of self-being alienated here and there, migrant writers of the second generation threw into relief these issues of identity, location, and origin.

Post-colonial peoples embody a hyphenated condition of identity, for example, IndoAmerican, Jamaican-Canadian, Indo-Pakistani Britisher. It is the phenomenon of having too many locations conciliating native and Western languages. However, their identities are linked only hypothetically and through hyphenation to specific geographic places while wandering at the margins of another's culture. Immigrants go into the world with a marginal sense of self. Thus, their relationship to their homelands and the Western countries they move to is characterized by ambivalence (Bhabha, 2004). They belong neither here nor there; so, the model of identity that results is a hybrid one that post-colonial peoples occupy, accept, and adapt themselves with the position of the in-between.

Migrant literature re-conceptualizes the notion of home from being a symbol of stability, comfort, and identity to one that foregrounds ambivalence, plurality, and fragmentation. The second generation of Caribbean writers, then, favors cosmopolitanism or internationalism, and relies on the dissolution and breaking up of boundaries. George (1999) explained, saying that home in the immigrant genre is a fiction that "one can move beyond or recreate at will" (p. 200). In other words, writers are no longer obsessed with the pleasures of feeling at home, or the burdens of homelessness, or the futile search of secure self-identity. Home, as a fixed and comforting anchor in one's life, is exposed as a myth and as an illusion.

In post-colonial novels today, the country to which the protagonist moves is no longer, as it once was, the old colonial London or Paris, but the new world power, the United States. Edmondson (1999) claimed that this difference in destination is precisely what distinguishes the first generation of predominantly male Caribbean writers "in exile" from the second generation of predominantly female "immigrant" writers. The first generation migrated to England in search of the literary authority associated with Cambridge and Oxford, while the heavily female contemporary migration to the United States is economically motivated, associated with physical, not intellectual labor. Consequently, the narratives of those women 
writers, according to Edmondson, "end and dissolve the opposition between the cultural remnants of the Afro-Caribbean space, on the one hand, and the industrialization and cultural changes that characterize contemporary Western society on the other" (p. 141). She implied that, because the authors themselves migrated to the States to better their lives, it makes sense that they depict characters who succeed in preserving their Caribbean cultural heritage, whatever it is, without sacrificing the economic aspirations that are associated with modernization. In this way, their protagonists create a space that re-conciliates progress and tradition, or, instead, keeps pace with modernization while preserving the homeland's history in one's memory.

Writers of different racial origins are now living in North America. They are United States citizens of different ethnicities as exiled and/or expatriated writers. They move back and forth between home and host nations, not out of necessity, but as a voluntary search for an improved life. Although they leave geographical spaces behind, they carry these spaces with them in memories. This suggests that the quest for roots and history also preoccupies the second generation in the process of migration. Boehmer (1995) underlined the ambivalence of migrant writers. She stated that, in making this move to richer places, writers have been much advantaged by the connections with Europe and America. She added that they have developed "a cosmopolitan tendency," but their work has remained a part and an expression of the "neocolonial world" (p. 238). In fact, the literature emphasizes the dynamic relationship between the past and the present and that history must be rewritten, rediscovered, and reinterpreted. This literature challenges the opposition between the modern and the traditional, the host country and the country of origin. This opposition motivates and stirs up the first generation's discourse of exile.

George (1999) indicated that the immigrant genre is marked by a detached reading of the experience of "homelessness," which is compensated for by excessive use of the metaphor of baggage, both spiritual and material. Immigrant novels suggest that immigrants must come to terms with the historical and cultural baggage they carry, or, rather, inherit. They should be aware of their roots and the history of their birthplace, remembering, rewriting, and reinterpreting it. Immigrants should carry the baggage of the past wherever they wander ( $\mathrm{p}$. 171).

In sum, post-colonial writing includes all twentieth-century literature produced from any place influenced by colonialism. The history of colonialism is shared by the whole world, though its impact varies with places and peoples. Immigration is one of the many manifestations of this common global history. Because colonialism is part of the historical baggage of all nations involved, the responsibility of post-colonial discourse is carried by writers whose personal histories include birth, childhood and possibly an early education in one of the former colonies. They represent the two sub-categories of post-colonial literature, namely, the literature of exile and what is called the "immigrant genre." Both were born of a history of colonialism, and are therefore participants in decolonizing discourses. Finally, Hall (1990) summarized all the Caribbean backgrounds included in this part. He wrote of the homelessness of the first generation of Caribbeans, or, rather, the old diaspora and the nomadic nature of the second generation or the new diaspora. He said,

It [the New World] also has to be understood as the place of many, continuous displacements: of the original pre-Columbian inhabitants, the Arawaks, Caribs and Amerindians, permanently displaced from their homelands and decimated; of other peoples displaced in different ways from Africa, Asia and Europe; the displacement of slavery, colonialism and conquest. It stands for the endless ways in which Caribbean people have been destined to 


\begin{abstract}
"migrate," it is the signifier of migration itself- of traveling, voyaging and return as fate, as destiny; of the Antillean, as the prototype of the modern or postmodern New World nomad, continually moving between center and periphery. (p. 225)
\end{abstract}

Hall's words convey the point that Caribbean migration did not only take place in the past, but still is occurring. There is a long history of migration, which started with the nomadic Amerindians, then went on with the European settlers, the African slaves, and the Indian indentured laborers. This history continues with the vast numbers of people who migrate to England or the United States, reproducing the original displacement and migration.

What follows is an examination of the British West Indies and the migration of people from there to Britain, descendants of the people who had been uprooted before to serve the British Empire. British West Indies are the territories in and around the Caribbean, including the countries of Central and South America, which were at one time colonized by the United Kingdom. They are Anguilla, Antigua and Barbuda, The Bahamas, Barbados, Belize, the Virgin Islands, Dominica, Grenada, Guyana, Jamaica, Saint Kitts and Nevis, Saint Lucia, Saint Vincent, Trinidad and Tobago, in addition to Turks and Caicos.

On June 21, 1948, the boat "Empire Windrush" brought over large numbers of Jamaican passengers to the United Kingdom. This arrival is often regarded as the starting point of twentieth-century migration to Britain, the start of a huge migration that brought later other thousands of Caribbean people (Ledent, 2007). This made Dabydeen (1989) say, as a joke, "that at the end of the twentieth century, Britain was the third largest Caribbean island, after Jamaica and Trinidad, with about half a million West Indian citizens" (p. 133). Because Britain was recovering then from an exhausting and ruinous war, West Indians were welcomed as so many helping hands in a country suffering from a labor shortage. Faced with the loss of empire after World War II, the British government needed skilled workers to reconstruct Britain from the war devastation and to redefine its national identity. Thus, it decided to rely on immigrant workers from the Caribbean (McDowell, 2018).

West Indian writers and artists joined these migrations. Pioneers in this movement were Barbadians George Lamming and Edward Kamau Braithwaite; Trinidadians Samuel Selvon, C. L. R. James, and V. S. Naipaul; Jamaicans Andrew Salkey and Stuart Hall; Guyanese Wilson Harris and Edgar Mittleholzer. A wave of West Indian writers immigrated to England in the fifties and perpetuated the history of displacement. They needed a vantage point outside the West Indies to write about their land. Lamming considered this migration as an inevitable direction in which aspirant writers would move (Lamming, 1960b).

The motivation to migrate was driven by economic motives; there were no major publishing houses in the Caribbean, and most important publishers were in London. Hence, migration meant the possibility of being published and attaining a broader readership. Thus, to develop their art, writers needed to come to terms with their colonial status. They had to fight to attain their significance and authority and win the respect and validation of their literary peers (Ledent, 2007).

In addition, colonial education had made Caribbean people look to Britain as the real world, the place where things could happen. Given a colonial education, West Indian writers came to Britain familiar with English manners, language, religion, and culture, which had dominated their imagination through the works of Shakespeare, William Blake, Charles Dickens, Jane Austen, and others. They planned to begin their second lives in Britain, with many dreams and expectations, especially for their children, who would have better opportunities in life than they could have in their homelands.

The immigrants thought they were going home, but reality appeared to be very different from the myth. The lives of immigrants in Britain were not easy due to discrimination. Ledent (2007) stated that it was true enough that there were jobs to be found at least up to the end of 
the 1960s. But the pay was low, and many West Indians were underemployed. They were put up in rundown accommodation, for which they were charged high prices. Discrimination in employment and housing made them realize that, before being British, they were Blacks (p. 2).

Kato (2002) claimed that these immigrants suffered discrimination in housing and employment, especially when the Black men had relationships with lower-class British women. British white men found this disgusting and abhorrent and often participated in race riots. The Caribbean Black presence in Britain was considered to be contaminating its racial and cultural "homogeneity" and purity. Even the conservative administration, which had decided to open Britain to Caribbean immigrants, discussed the possibility of using the slogan "Keep Britain White" in the 1955 election campaign. The hostility among British people toward the Caribbean immigrants rose to the extent that those immigrants had to hear the rebuke "Go back to the jungle," and had to suffer "unprovoked physical attacks" (pp. 122-123).

As a matter of fact, there had been a significant Caribbean presence in Britain for centuries. The expansion of the slave trade and of slavery in the West Indies brought about an increase of the Black population in Britain itself. Blacks accompanied their masters to Britain and lived mainly as servants to those masters, which explains the presence of Blacks, not only in London but in rural areas as well. Their presence in Britain was disliked even in the period of Queen Elizabeth I, and she often tried to expel them from the land. But such efforts failed due to the profitability of the slave trade and slavery. According to a magazine, their number reached 20,000 in 1764, and worried voices and complaints about their presence began to be raised in London in the 1770s (Kato, 2002). Hence, racial prejudices against blacks awaited the arrivals of black Caribbeans when they immigrated in a mass to Britain after World War II.

The flow of Caribbean immigrants to Britain opened a new space for the flowering of Caribbean rooted literary activity. West Indian writers began to write about the lack of housing and the open hostility of their hosts. George Lamming was the first to deal with this problem in his 1954 novel, The Emigrants, which traced the journey on a boat to Britain and the disappointment of many of the migrants as they struggled to seize the opportunities and new freedoms presented by Britain.

Samuel Selvon's, The Lonely Londoners (1956), depicts the contradictory tension in Selvon's attraction to and rejection by England. These issues forced Anglo-Caribbean people to re-assess their status as colonials and rediscover their own identity and values. Immigration to Britain, then, helped to create a feeling of "Caribbeaness," or, rather, West Indianness. Firstgeneration literature, therefore, was shot through these uncomfortable anxieties of belonging and not belonging, and depictions of the experiences of growing up as Black Caribbeans in a white British environment. Vic Reid, for instance, published New Day in 1949. Samuel Selvon wrote A Brighter Sun (1952), which depicts the life of a young Indian boy in the Trinidad of the war years. George Lamming wrote In the Castle of My Skin (1953). This was the Caribbean region's first major fictional work in English. Also, Colin MacInnes began to chronicle the new arrivals in two books, City of Spades (1957) and Absolute Beginners (1959). In these two books, he recognized the newcomers as predicting a wider social transformation in Britain because they are seen as the owners of alternative and anti-British sources of cultural resistance through music, nightclubs, fashion, and attitudes.

There were more works produced in this genre. V. S. Naipaul penned Mystic Masseur (1957), while the Indian Nirad Chaudhuri wrote A Passage to England (1959), followed by Naipaul's Miguel Street (1959). In Naipaul's A House for Mr. Biswas (1961), he tackled and developed the themes of freedom and independence. Lamming's later novels, Of Age and Innocence (1958) and Season of Adventure (1960a), developed these themes further. Others, like the Guyanese writer Wilson Harris in Palace of a Peacock (1960), and Andrew Salkey in A Quality of Violence (1959) looked to older Amerindian and African influences as a source of ideas for locating the identities of these new countries. C. L. R. James, shortly after, published 
Beyond a Boundary (1963), in which he examined the struggle with the British inheritance and the necessity of forging new post-colonial identities.

Accordingly, a process of rediscovery was illustrated in the creativity of the Caribbean writers exiled in Britain from the 1950s onwards. They built on the writing of others, like Jean Rhys, who settled in Britain in the 1930s. Other writers, like Jomo Kenyatta, Hastings Banda, Marcus Garvey, and George Padmore, had already come to study, agitate against colonialism, and publish their works.

Caribbean authors not only wrote about their experience as exiles but also about Caribbean society, which they saw clearly from a distance. They produced numerous responses to the history of displacement and migration. Those writers felt a need and a duty to represent colonial societies and to reveal the humanity of their people to a Britain ignorant of that humanity. They express the feeling of rootlessness and the need to be rooted; so, they delve deep into an understanding of their origins and their position. Fighting the conqueror's assumptions and representations, Anglo-Caribbean writers began to develop a tradition focusing on Caribbean consciousness, departing from mere imitation of the conventions of the European colonizers. In fact, the Caribbean has been the source of the most challenging postcolonial literary theory. Built around the concepts of otherness, resistance, and hybridity, it focuses on the mingling of cultural practices from the colonizing and colonized countries (Ashcroft, 2017; Tolba, 2018).

The single literature developing across the lands was encouraged, in the 1940s, by the BBC radio- program, "Caribbean Voices," which broadcast stories and poems written by West Indian authors. "Caribbean Voices" began its run in 1946. It was a weekly program which "focused 20 minutes- 29 minutes after 1947- of "valuable air time on the literary output (short stories, poems, plays, and literary criticism) of the Caribbean region" (Wambu, 2011, para. 8). The program shed light on the careers of individuals like George lamming, Edward Kamau Braithwaite, V. S. Naipaul, Sam Selvon, Wilson Harris, Jamaican John Figueroa, and St. Lucian Poet Derek Walcott. The program also helped them get publishers, and, after they had arrived in Britain, provided them with work as readers. Wambu noted that all the major writers of the region acknowledged the importance of the program; he referred to Braithwaite, who said that "Caribbean Voices" was the single most important literary incentive for Caribbean creative writing in English.

The first-generation Caribbean Writers in Britain lived in dual homelessness; in their countries of origin or abroad, they were homeless. Hence, their exile was a search for a true home, and, in their writings, they attempted a personal and literary search for a space that expressed the reality of the West Indian identity. Exiled writers have provided an objective view of the two worlds, the Caribbean and the European, and they avoided taking sides due to their alienation in both. It is this detachment that has brought forth their literary creativity. They assumed the status of in-betweens, mediators between two cultures, a romanticized England and an alienating Caribbean.

With this Anglo-Caribbean literary activity, the "Caribbean Arts Movement" emerged. It struggled with issues of Caribbean artistic identity and was concerned with uniting all Third World peoples, whether they were in Europe or back in the West Indies. This movement drove the opening of the first grassroots bookstores and publishing houses, such as Trinidadian John La Rose's New Beacon bookstore, Guyanese Jessica and Eric Huntley's L'Ouverture, and Trinidadian Darcus Howe's Race Today Publications. These and others were the key players in the move to establish more publishing houses promoting new Black writing, as well as reissuing old classics. Put differently, they conveyed the voice of the first-generation of Anglo-West Indian writers who announced the birth of Caribbean literary consciousness.

The second generation of Anglo-Caribbean writers was born in the West Indies in the 1950s but was brought up and/or educated in Britain, where most of them arrived as children or teenagers. Hence, they were the inheritors of a complex tradition. These writers include 
David Dabydeen, Fred D'Aguiar, Caryl Phillips, and Joan Riley. Their writings owe much to the groundbreaking first generation. The younger writers did not have the same culture shock as the first generation, who arrived in England as adults and with a colonial background. Nevertheless, they lived, like their predecessors, at the borderline of - at least- two cultures.

The second generation includes novelists who came to England with different expectations from those writers who arrived as children. They belong to a group imbued with the myth of Britain as the land of milk and honey, and, so, came to England to seize economic opportunities. This group included Buchi Emecheta and Beryl Gilroy, who published The Black Teacher (1976) about her time working in North London. The generation also included AngloCaribbean novelists based in and brought up in the United States. Their origins affected their work in the same way as that of other writers of their generation living in the United Kingdom. However, their art came from a different social and literary context than that of their peers brought up in Britain. Among these writers are Jamaica Kincaid (Antigua-United States), Michelle Cliff (Jamaica-United States), Paule Marshall(Barbadian-African American), Opal Palmer Adisa (Jamaica-United States), and Trinidadian Earl Lovelace, who divides his time between the United States and Trinidad, as does St. Lucian Derek Walcott.

Wambu (2011) claimed that Caribbean publishing houses were crucial in developing and publishing new talent that was shaped and molded in Britain. Race Today publications and L'Ouverture heralded the emergence of the voice of those who grew up in Britain and who were not ready to put up with its race-based culture in the same polite way that their parents had done. Wambu referred to the radicalization that occurred among Anglo-Caribbeans who, unlike their West Indian immigrant parents, were militants claiming their rights as British citizens. Many refused to do the mean and unpleasant jobs that their parents accepted. Their resistance was crucial in creating a Black community and starting a revolution. Phillips, one of the secondgeneration Anglo-Caribbeans, who had been brought up in Britain, explained, in A New World Order (2002), the difference of the first and second generation of immigrants as follows:

\begin{abstract}
By the 1970s, their children's generation, my generation, was still being subjected to the same prejudices which had blighted their arrival, but we were not our parents. You might say we lacked their good manners and their ability to turn the other cheek. Whereas they could sustain themselves with the dream of one day 'going home, 'we were already at home. We had nowhere else to go and we needed to tell British society this. The 1976 and 1977 Nothing Hill riots were born out of this frustration. (p. 242)
\end{abstract}

Phillips referred to the riots between British West Indians and the British police that began in the 1950s. West Indian culture indeed became transplanted into the British soil, an example being the West Indians' Notting Hill Carnival. He stated that the Trinidadians introduced the tradition of Carnival to Britain; it is characterized by wearing costumes to participate in masquerade, and dancing through the streets to the sounds of the steel band percussion. The continued presence of the Notting Hill Carnival shows the refusal of West Indians to have their culture taken away from them, and their desire to pass on this culture to their Black British children. Moreover, they gained power through the use of patois and dialects as a deliberate misuse of the English language. It is this broken form of English that was used by the Blacks, and which shows how language is a powerful way to affirm culture and identity.

Ledent (2007) noted that Anglo-Caribbean writers are sometimes labeled "Black British," which seems basically misleading. First, it sets artificial boundaries to the creative imagination and seems inappropriate with reference to a writer like Caryl Phillips, whose work presents a cross-cultural vision of the world. Second, this category "Black British" covers too 
broad a literary territory, by including immigrants from Asia and Africa, in addition to the Caribbean. Thus, the term can be used to identify writers like Ben Okri from Nigeria, or Salman Rushdie and Hanif Kureishi of Indo-Pakistani origin. Put another way, the term is not limited to the Caribbean. It can define other writers like the South Asian Meena Alexander, Padma Perea, and Bharati Mukherjee. Accordingly, Instead of "Black British," Ledent proposes to use the category "Caribbean Diaspora in Britain" or the "New Diaspora" for short (p. 5).

One might say that, in this context, the category "Caribbean Diaspora in Britain" is more suitable, as it implies the generation's homelessness and its many borderline cases with multiple locations. It also suggests the writers' new attitude towards the issue of home. They are caught between the old and the new, past and present, home and host country. Fred D'Aguiar and Caryl Phillips, who belong to this generation, spend much of their time in the United States for professional reasons. Still, their outlook remains basically shaped by their British experience. Most of these writers inhabit two cultural spaces. They exemplify the paradoxical reality of belonging and not belonging, and of being inside and outside of culture. Their writings reflect an assertion of their right to belong to British society and a repossession of a history hidden and misrepresented. They have a past West Indian identity which they bring to bear on Britishness.

Consequently, in the mid-1970s, these new voices were being heard. A shift in focus is apparent among them, as the younger Anglo-Caribbean authors began to publish. They are writers of Caribbean heritage freed from the colonial complex; they are driven by a sense of identity, one that is multifaceted or fluctuating.

In the mid-1980s, second-generation writers were the leaders of a movement that carried a new wave of creativity to rival the pioneers of the 1950s. These writers introduced a literature that looked back to its source, namely, first-generation literature, but with writers far more selfconfident about their position in Britain. This was a literature that would not be marginalized or put at the edges. Instead, it would be a part of the broad range of British writing, with its writers moving from post-colonialism to multicultural Britain.

The older writers of the first generation like Lamming, E.R. Braithwaite, Sam Selvon, and Andrew Salky, were getting to the point where they could not chronicle the energy of the new Britain. Thus, between the 1970s and 1980s, they began to take up positions in the Caribbean, the United States, or Canada. V. S. Naipaul, meanwhile, continued to produce major novels, such as A Bend in the River (1979), not directly written about Britain.

By the late 1980s, the major writers who had emerged at the start had begun to strengthen their position. Caryl Phillips's The Final Passage (1985) and Joan Riley's The Unbelonging (1985) rewrote the story of the arrival of their parents, namely, the first-generation Anglo-Caribbeans. Mike Phillips explored in Blood Rights (1989) the complicated and mixed heritage of Black and white Britons. Some of the older writers, V. S. Naipaul, in particular, began to deal with Britain. His novel, The Enigma of Arrival (1987), explored the English countryside and his relationship with both it and the nation, which had dominated his imagination for so long.

The difficulty of ever returning to the Caribbean "home" is a major preoccupation of the New Diaspora. This difficulty is expressed in the novel The Unbelonging (1985) by the Jamaican writer Joan Riley and in Caryl Phillips' A State of Independence (1986). Ledent (2007) saw The Unbelonging as one of the first novels of the New Diaspora published by a Caribbean woman writer in Britain since Jean Rhys' novels in the 1930s. Ledent considered it as one of the few novels, along with Caryl Phillips's The Final Passage(1985), to offer a woman's perspective on Caribbean migration to the United Kingdom. Thus, it prefigures the emergence of a tradition of women's writing still in the making. Ledent added that the novel is emblematic of a whole generation (p. 8).

The Unbelonging dramatizes the dilemma of a generation that feels at home neither in England nor in its native Caribbean. It tells the story of Hyacinth, a teenager who arrives in England in the 1970s. Faced with an abusive father and hostile schoolmates, she retreats into 
her dream of an idealized Jamaica, which turns into a nightmare when, after taking a degree, she journeys back to the Caribbean. There, she is brutally confronted with her ultimate homelessness when the "Go back whe yu fram" of Jamaicans echoes the "Go back where you belong" of racist Britons. Both tell her that she is rejected in both England and Jamaica. She is homeless in her place of birth and in the host country to which she had immigrated.

Most novels of the New Diaspora deal with the family as a site of disruption and splitting, and as a metaphor of the post-migration condition. The colonial trauma has not ended with exile; it has repeated itself at the level of the family. Kundera (2005) claimed that the family functions with the same psychological stressors as society at large (p. 109). The abusive behavior of Hyacinth's father and his physical violence in The Unbelonging have clear colonial overtones. They are one instance of the New Diaspora's representation of colonial and sexual victimization.

David Dabydeen's The Intended also provides a good example of family problems. It centers on a nameless teenager who, away from his native Guyana, is abandoned by his father and put into the care of the English social services. The novel implies that an institution plays the role of a surrogate parent, providing the material, but not the psychological, needs of the child. Ledent (2007) said that this also plays out in the lives of Caryl Phillips' heroines. Leila, in The Final Passage (1985), is cared for by a health visitor, while both Irina and Eva leave their families in Poland and Germany to land in the care of a landlady and the National Health Service (p. 15).

Parental surrogacy is a distinctive feature in the writing of the New Diaspora. It appears in Phillips' Crossing the River (1993), which is a novel that addresses cross-cultural experiences through imaginative journeys in the history of the African diaspora. The image of surrogacy in the novel is that of an African father who sells his three children into slavery and, in this way, initiates the African diaspora, but he finally makes a white English woman one of his own children. Moreover, in Phillips's A Distant Shore (2003), Gabriel, a refugee from Africa whose family has been destroyed by war, is received by a couple of older Britons who regard him as the son they never had.

Obsession with memory is another major concern in the writing of the second generation. Flashbacks set in the native land or Africa suggest that the writers had to come to terms with their past before handling the present. The exploration of the past characterizes many novels of this second generation writers. David Dabydeen's The Counting House (1997), explores the arrival of Indian laborers in nineteenth-century Guyana. Fred D'Aguiar's, The Longest Memory (1994), offers a reconstruction of the past as a way of understanding its complexities.

Ledent (2007) said that "the polyphonic structure of the historical novels of the New Diaspora signals compassion for the dispossessed and the victims, regardless of their race or origin" (p. 12). Although the colonial system might be officially over, there remains a larger oppressive order, economic and patriarchal, which preoccupies these writers. There is a growing concern for woman as other and outsider, and the focus on more domestic issues like man/woman relationships. Phillips' novels, for instance, exemplified this sympathy with the other. His recreation of female voices shows his understanding of marginalized characters, whether Black or white. There also is his interest in the Jewish experience in The Nature of Blood (1997) in addition to his diasporic vision in Crossing the River.

Second generation writers called into question the myth of British homogeneity and superiority. Put differently, they led to a redefinition of Britishness that copes with plurality and includes the outsider. Ledent (2007) quoted Phillips' words in the introduction to Extravagant Strangers, an anthology devoted to writers born outside Britain, but who are part of its literary tradition. According to Ledent, Phillips said, "Britain has developed a vision of herself as a nation that is both culturally and ethnically homogeneous, and this vision has made 
it difficult for some Britons to feel that they have the right to participate fully in the main narrative of British life" (p. 13). His words show how he is against the notion of British homogeneity and the distinction it bestows upon itself. The words also imply that he and his fellow Anglo-Caribbean writers support British heterogeneity, which has for too long remained unrecognized.

Ledent (2007) indicated that what distinguishes the new generation's approach from that of their predecessors is a "changing sameness," a matter of different emphasis. While the project of the first generation of Caribbean writers was based on "the desire to voice a specific identity in the face of a dehumanizing colonization, that of the second generation addressed the problem of the Westernized foreigners" (p. 14). She actually means that the writing of Black Britishers, assert their right to belong to British society and to repossess a history that has been silenced or partially represented.

What also characterizes the writings of the second generation is an increased emphasis on the individual. West Indian writers of the 1950s and 1960s concentrated on the oppressed and uprooted inhabitants of colonized islands as the inheritors of a traumatic past. However, many writers of the younger generation, such as Jamaica Kincaid, Earl Lovelace, and Erna Brodber, have turned their attention to other concerns. They have achieved a sense of their own identity and are interested in the individual for his or her own sake. With the history of migration to England and the United States, individuals are not to be defined in absolute oppositional binary, either West Indian or Black British.

On the contrary, they are comfortable in the in-between location. Second-generation Anglo-Caribbean writers, side by side with other Black Britishers, seek their own and their characters' identities among immigrants and expatriates. They bring a new dimension to the contemporary novel in England, "the immigrant novel," or the "cosmopolitan novel." The shift from the literature of exile to migrant literature challenges the binary logic of "here" and "there," emphasizing movement, rootlessness, and the mixing of cultures, races, and languages.

To counterbalance such a concentration on subjectivity or individuality and the psychological explorations of suffering it brings, second-generation Anglo-Caribbeans have simultaneously focused on a more general and universal perspective. In attempting to heal the Caribbean fragmentation and disintegration, they turn the attention to a larger frame of reference that goes beyond the Caribbean plight to include the diasporic world at large. Most second-generation writers have a sense of collective responsibility, not only to their people but also to the human race as a whole. This is the transitional generation that has built bridges between the past and the future.

In their novels, the writers of the second generation portray migrants wandering without a fixed home. Their movement between multiple locations suggests co-belonging. Diasporans' origin haunts them, but it is elsewhere that they have set their hopes and ambitions. Thus, the immigrant faces a mixture of contradictory trends: home hunting to create space in the world and home haunting, motivated by a desire for cultural reconnection and a kind of nostalgia for restoring a home that has been lost. Diasporans carry with them their Caribbean home while making connections in another space.

Situated in this challenging position between "here" and "elsewhere," diasporans must establish a new sense of home. It is a rehoming process for those who had already been dehomed when they were uprooted. Their state of homelessness has led to the desire for rehoming. They are presented in Anglo-Caribbean literature as strangers from elsewhere who, without a sense of belonging, never feel at home in a new country. Yet, they are unable to return to their native country. If they return, they feel estranged from their ancestral home. This creates in them a psychological sense of foreignization in which one becomes a homeless other. Thus, to rehome, that is, to create a sense of home within one's self, diasporans must learn how to live with the others and live like others. They must accept the many changes and transformations that have happened to home as a closed structure. 
Modern diaspora and the transfer of peoples and cultures from all over the world to England, the United States, and Canada has generated cultural globality that disrupts this closed structure. Accordingly, being at home for diasporans is interacting with a wide range of places and cultures, while maintaining a connection with the history of their country of origin and preserving its heritage. This point is emphasized through Caryl Phillips' words in A New World Order (2002). He said, "Caribbean people are forever moving between versions of home, spurred on by the restless confluence of blood in their veins, an impure mixture that suggests transcendence and connectivity" (p. 131). He means that the nomadic nature of the West Indian immigrant has generated a pluralized concept of home. Instead of one home, there are many homes, mixed origins, and mixed cultures. The movement from place to place transcends home in moving toward openness and connection.

Ledent (2016) saw a fluctuation in the canonization, or even appreciation, of the emerging Caribbean authors, and their acceptance as part of the British literary scene. The process is "White dominated," relying on changeable indefinite criteria of race, gender, and class. More than that, some Black British writers "are more British than others, not because of their race, ethnicity, or even the quality of their literary work. Instead, it depends on their political stances and their general attitude to the British literary system" (p. 243). Nevertheless, Ledent stressed the idea that Black British writers in Britain, with their creativity, will be able to change the map and develop a new image. She said, "what is certain in this stage is that in a matter of six decades, the writers of Africa, Caribbean and Asian heritage in Britain, canonized or not, has changed the face of the national literary tradition forever" (p. 252).

\section{Findings}

Digging deep into the contemporary state of the Caribbeans, I have found that suffering and resistance is still an ongoing and interrelated process in Britain and the United States. Black British people and African-Americans do strive to fix their identities and attain their rights. The findings to follow are in line with what has been traced and documented about the impressive history of the Caribbean and the never fainting responses of its writers to the region's painful realities.

Webster (2018) indicated that Caribbeans "have been told recently that they do not belong to Britain.... But they are no strangers to feelings of unbelonging [that] often feature strongly in their stories of early life in Britain" (p. 1). The myth of the "mother-country" is a failure; the Windrush generation has found that they are mere immigrants, dark strangers who never belong. They and their children still experience discrimination and fight against it. Webster added that "white Britons, who are ignorant about the British empire, do not know or acknowledge that Caribbean migrants are also British. "Instead, they are seen as bringing an "alien color problem" into Britain....The Home Office [decides] to restrict the rights of Windrush generation arrivals and their children, and to threaten them with deportation[which] ranks among the most shameful episodes in Commonwealth history" (p. 2). In fact, events are held annually on June 22 to celebrate the Windrush's arrival 72 years ago as the first in a wave of immigrants from Caribbean countries, brought to Britain to rebuild the country. But I see that Britain's gratitude for the immigrant's work is questionable.

In 1965, the British Parliament passed the first Race Relations Act to protect newly arrived migrants from South Asia and the Caribbean. Nevertheless, discrimination is still a reality; ethnic minorities are "less likely to be hired than comparable white British workers" (Fernández-Reino, 2020, para.4).Black people are seen as belonging in the British empire, not in Britain. Even children, who expect to be treated as White British, feel there is discrimination. This is reported by adult children of migrants, who were born and raised in the United Kingdom (Fernández-Reino, 2020). 
On the literary side, Caribbeans never forget the early contributions of their writers, those who laid the foundation for a literary heritage that raised the voice of West Indians around the world. A conference celebrating Andrew Salkey's legacy was held on June 20, 2020, at the University of London. He is a central figure in a circle of Caribbean writers, artists, and intellectuals. He is also a broadcaster who played a big role in supporting Caribbean writers. He devoted himself to literary activism across the Caribbean diaspora. The Andrew Salkey archive was opened to researchers in Autumn, 2020 (Creative Activism Now, 2020).

From the 1900s on, the United States has been a major destination for migrants. The repeating pattern of unjust murders of African Americans is related to "a systemic, institutionalized anti-Black racism" (Members of the Caribbean Community, 2020, para. 2). On May 25, 2020, members of the Caribbean community, with voices raised all over the world, denounced the killing of African- Americans by police in the United States. They sent a letter to the Prime Minister of Barbados and reminded all of how they shared a common history serving the Western Empire (Members of the Caribbean Community, 2020).

Solidarity was emphasized when the movement "Jamaica Northeast Diaspora" celebrated diaspora week in June 2020. The theme of this event was "Unity and Resiliency," calling for equal rights and justice (Bakalar, 2018; jamarch, 2020). Other movements, like "Black Lives Matter," condemned the horrors of violence perpetrated on Black people in North America, reminding U.S. citizens of their racist beliefs, their stereotypes, and exploitation policies ingrained in the culture since colonialism. At the same time, protests were propelled by the pandemic in which African-Americans have been the most impacted by Covid-19 due to "existing health disparities" (Nixon, 2020, p. 1).

The Center for Interdisciplinary Research $(\mathrm{ZiF})$, in collaboration with the Black Americas Network, and the Center for InterAmerican Studies (CIAS), has organized an international conference to be held in July 2020 in Bielefeld, Germany. The conference is titled "(Re-)Thinking Home: 21st-Century Caribbean Diaspora Cultures and Geopolitical Imaginaries." The coordinators indicated that the conference will focus on the Caribbean literary creativities and the cultural activities of the Caribbean diaspora in the latter part of the $20^{\text {th }}$ and the early $21^{\text {st }}$ century in North America. Actually, this conference reminds one of Caryl Phillips' notion of rehoming, which has been referred to in this paper. Organizers noted that "there is an interaction between Caribbean/Canadian and Caribbean/US cultural and literary products" in an attempt "to(re-)invent home and belonging in a globalizing present." Home is never closed but "(trans-)locatable, both material and imaginative....home becomes homes." (Redaktion, 2019, para. 1).

To make the story short, these findings bring to light the resiliency of the Caribbeans in fighting for their rights and the richness of an influential Anglo-Caribbean diasporic literature.

\section{Discussion and Conclusion}

This paper documents the Caribbeans' story and their long journey of suffering and resistance. It explores the historical and the contemporary Caribbean world in building the diasporic culture of Anglo-Caribbean communities. The study indicates how migrations, motivated by personal, economic or professional reasons, are rooted within the post-colonial history and represented in today's imperialist dominations. It then focuses on Anglo-Caribbean writers through two generations and how they are preoccupied with Caribbean dilemmas. They share an exploration of their birthplace and their relationship to it. They, along with writers in other parts of the Caribbean islands, stress the responsibility of colonialism and neocolonialism for creating a diasporan world. They reveal and denounce the ravages of colonialism, encouraging both the ex-colonizers and the ex-colonized to find solutions to the Caribbean problem. Furthermore, with its reference to Anglo-Caribbean writers, the paper indicates how they create a literature of resistance that cannot be ignored. They have made use 
of their colonial education, their study of English literature, and their Caribbean creativity to stand against the Western line of thought.

The findings comport with what have been handled in this study and other similar ones. These findings emphasize the never-failing Caribbean resistance to discrimination, as well as the richness of a very promising diaspora literature. Hopefully, this paper provides an understanding of Caribbean history that encourages the young white generation to support the oppressed and contribute to the process of healing the traumas of the Caribbean.

Pursuing the story of the uprooted Caribbeans definitely urges one to ponder on the significance and the universal message it conveys. The study sheds light upon man's crisis on earth. With the increase of man's ambitions and greed, and with the ascendancy of the bad side over the good, everything is disturbed and unbalanced; homes are lost, and people are displaced. Man begins to reveal his destructive ideas such as survival for the strongest, racism, racial superiority, exploitation, monopoly, expansion, and occupation. The outcome is horrible human suffering and everlasting conflicts. This is the way things are in our life: homeliness and homelessness, settlement and displacement, subjugation and resistance. In the end, it all depends on the role every one of us plays and for which he or she is responsible in this life and in life after.

Further research should deal with other parts of the Caribbean region, such as the Hispanophone and Francophone territories, tackling their literary contributions. Besides, research should be dedicated to the problems of Middle East immigrants in the Western world, their struggle against racism, and the false ideologies directed against them.

\section{References}

Addai-Mununkum, R. (2019). Students' representation of "other" religions. Journal of Curriculum Studies Research, 1(1), 1-16. https://doi.org/10.46303/jcsr.01.01.1

Akinsola, I. T. (2020). Nollywood Reception Preferences among Selected Multilingual Nigerian Undergraduates in the University of Ibadan: Does Ethnicity Still Matter?. American Journal of Qualitative Research, 4(1), 3848. https://doi.org/10.29333/ajqr/8210

Appiah, K. A. (1998). The dictionary of global culture. Vintage.

Ashcroft, B. (2017). Postcolonial Theory. Wiley Online Library. https://doi.org/10.1002/9781118430873.est0281

Bakalar, B. (2018). Book Review: Justice on both sides: Transforming education through restorative justice. American Journal of Qualitative Research, 2(2), 145-149.

Bhabha, H. K. (2004). The location of culture (2nd ed.). Routledge.

Boehmer, E. (1995). Colonial and postcolonial literature. Oxford University Press.

Brodsky, J. (1991). The condition we call exile. Renaissance and Modern Studies, 34(1), 1-8. https://www.tandfonline.com/doi/abs/10.1080/14735789109366539 doi: 10.1080/14735789109366539

Carew, J. (1978). The Caribbean writer and exile. Journal of Black Studies, 8(4), 453-475. https://doi.org/10.1177\%2F002193477800800404

Cesaire, A. (2000). Discourse on colonialism. Monthly Review Press. https://libcom.org/files/zz_aime_cesaire_robin_d.g._kelley_discourse_on_colbook4m e.org_.pdf

Chaudhuri, N. C. (1959). A passage to England. Macmillan.

Cliff, M. (1984). Abeng. Crossing Press.

Cliff, M. (1985). The land of look behind. Firebrand Books.

Cliff, M. (1991). A woman who plays trumpet is deported. In M. Cliff (Ed.), Bodies of water (pp. 55-60). Plume/Penguin. 
Creative Activism Now. (2020, June 20). Goldsmiths: University of London. https://www.gold.ac.uk/caribbean/conferences/

D'Aguiar, F. (1994). The longest memory. Vintage Books.

Dabydeen, D. (1989). On not being Milton: Nigger talk in England today. In M. Butcher (Ed.), Tibisiri: Caribbean writers and critics (pp.116-135). Dangaroo Press.

Dabydeen, D. (1991). The intended. Martin Secker \& Warburg Ltd.

Dabydeen, D. (1996). The counting house. Peepal Tree Press.

Dabydeen, D. (1999). A harlot's progress. Vintage.

Edmondson, B. (1999). Return of the native: Immigrant women's writing and the narrative of exile. In Making men: Gender, literary authority, and women's writing in Caribbean narrative (pp.139-168). Duke University Press. https://doi.org/10.1215/9780822397236-006

Fernández-Reino, M. (2020, January 30). Migrants and minorities: Britain's pride and prejudice. https://www.politics.co.uk/comment-analysis/2020/01/30/migrants-andminorities-britain-s-pride-and-prejudice

George, R. M. (1999). The politics of home: Postcolonial relocations and twentieth century fiction. University of California Press.

Gikandi, S. (1992). Writing in limbo: Modernism and Caribbean literature. Cornell University Press. www.jstor.org/stable/10.7591/j.ctt207g6bv

Gilroy, B. (1976). The Black teacher. Cassell.

Hall, S. (1990). Cultural identity and diaspora. In J. Rutherford (Ed.), Identity (pp. 222-237). Lawrence and

Wishart. http://sites.middlebury.edu/nydiasporaworkshop/files/2011/04/D-OA-HallStuartCulturalIdentityandDiaspora.pdf

Hall, S. (2001). Negotiating Caribbean identities. In B. Meeks \& F. Lindahl (Eds.), New Caribbean thought: A reader (pp. 24-39). University of the West Indies Press. https://www.questia.com/read/105182141/new-caribbean-thought-a-reader

Harris, W. (1960). Palace of a peacock. Faber and Faber.

Harris, W. (1996). Jonestown. Faber and Faber.

Hearne, J. (1961). Land of the living. Faber and Faber.

Hoetink, H. (1982). The Dominican people 1850-1900: Notes for a historical sociology. The Johns Hopkins University Press.

jamarch. (2020). Unity and resiliency: Jamaica Northeast Diaspora, USA celebrates diaspora week, June 14-20, 2020. https://news.jamaicans.com/unity-and-resiliency-jamaicanortheast-diaspora-usa-celebrates-diaspora-week-june-14-20-2020/

James, C. L. R. (1963). Beyond a boundary. Hutchinson.

John, C. (2005, December 13). Four decades of UK race law. BBC News. http://news.bbc.co.uk/2/hi/uk_news/4510062.stm

Juneja, R. (1996). Caribbean transactions: West Indian culture in literature. Macmillan.

Kato, T. (2002). Caryl Phillips as a Black British writer: The experience of Caribbean immigrants after World War II. Ristsumeikan Annual Review of International Studies, $1,121-132$.

Kundera, M. (2005). The art of the novel. Faber \& Faber.

Lamming, G. (1953). In the castle of my skin. Michael Joseph.

Lamming, G. (1954). The emigrants. The University of Michigan Press.

Lamming, G. (1958). Of age and innocence. Michael Joseph.

Lamming, G. (1960a). Season of adventure. The University of Michigan Press.

Lamming, G. (1960b). The pleasures of exile. Michael Joseph.

Ledent, B. (2007). Caribbean literature: Looking backward and forward. Vetas Digital, 5(7879), https://pdfs.semanticscholar.org/c51f/82f15b0f7b904f6338ddbe7da2f9cf94a252.pdf 
Ledent, B. (2016). 'Other' voices and the British literary canon. In D. Osborne (Ed.), The Cambridge companion to British Black and Asian writing, 1945-2010 (pp. 241255). Cambridge University Press. https://www.researchgate.net/publication/333429787_'Other'_Voices_and_the_British _Literary_Canon and https://www.academia.edu/29894672/Other_Voices_and_the_British_Literary_Canon Ledent, B. (2017). Caribbean writers and the Jewish diaspora: A shared experience of otherness. In G. Collier, G. Davis, M. Delrez, \& B. Ledent (Eds.), The cross-cultural legacy: Critical and creative writings in memory of Hena Maes-Jelinek (pp.201-218). Brill/Rodopi. https://doi.org/10.1163/9789004338081.

Ledent, B., O'Callaghan, E., \& Tunca, D. (2018). Madness is rampant on this island : Writing altered states in Anglophone Caribbean literature. In L. Bénédicte, O. Evelyn, \& T. Daria (Eds.), Madness in Anglophone Caribbean literature: On the edge ( pp. 1-17). Palgrave Macmillan. https://doi.org/10.1007/978-3-319-98180-2_1

Lowenthal, D. (1978). West Indian Societies. Oxford University Press.

MacInnes, C. (1957). City of spades. Hart-Davis, MacGibbon.

MacInnes, C. (1959). Absolute beginners. Hart-Davis, MacGibbon.

Mardorassian, C. M. (2002). From literature of exile to migrant literature. Modern Language Studies, 32(2), 15-33. https://doi.org/10.2307/3252040

Marshall, P. (1969). The chosen place, the timeless people. Harcourt, Brace, \& World.

McDowell, L. (2018, October 4). Windrush stories: How Caribbean migrants helped to rebuild Britain. The British Library. https://www.bl.uk/windrush/articles/how-caribbeanmigrants-rebuilt-britain

Members of the Caribbean Community. (2020, June 8). Caribbean people stand in solidarity against anti-Black state violence in the USA. Stabroek News. https://www.stabroeknews.com/2020/06/08/features/in-the-diaspora/caribbean-peoplestand-in-solidarity-against-anti-black-state-violence-in-the-usa/

Naficy, H. (1993). The Making of Exile Cultures: Iranian Television in Los Angeles. University of Minnesota Press.

Naipaul, V. S. (1957). Mystic Masseur. Andre Deutsch.

Naipaul, V. S. (1959). Miguel Street. Andre Deutsch.

Naipaul, V. S. (1961). A house for Mr. Biswas. Andre Deutsch.

Naipaul, V. S. (1979). A bend in the river. Knopf.

Naipaul, V. S. (1987). The enigma of arrival. Viking Press.

Nixon, A. V. (2020, June 15). Black lives matter-What does it mean for us in the Caribbean? Stabroek News. https://www.stabroeknews.com/2020/06/15/features/in-thediaspora/black-lives-matter-what-does-it-mean-for-us-in-the-caribbean/

Phillips, C. (1985). The final passage. Faber and Faber.

Phillips, C. (1986). A state of independence. Farrar, Straus, \& Giroux.

Phillips, C. (1989). Higher ground. Viking Press.

Phillips, C. (1993). Crossing the river. Bloomsbury Publishing.

Phillips, C. (1997). The nature of blood. Knopf.

Phillips, C. (2002). A new world order. Vintage International.

Phillips, C. (2003). A distant shore. Knopf.

Phillips, M. (1989). Blood rights. Dell Publishing.

Redaktion. (2019, March 15). Call for papers: (Re-)Thinking home: 21 st-century Caribbean diaspora cultures \& geopolitical imaginaries in North America. Center for Interdisciplinary Research (ZiF). Bielefeld University.

Reid, V. (1949). New day. Knopf.

Rhys, J. (1966). Wide Sargasso Sea. W. W. Norton Company. 
Riley, J. (1985). The unbelonging. Woman's Press.

Roberts, P. A. (2007). West Indians and their language (2nd ed.). Cambridge University Press.

Safran, W. (1991). Diasporas in modern societies: Myths of homeland and return. Diaspora: A Journal of Transnational Studies, 1(1), 83-99. https://doi.org/10.1353/dsp.1991.0004

Salkey, A. (1959). A quality of violence. New Authors Limited, Hutchinson.

Selvon, S. (1952). A brighter sun. Alan Wingate.

Selvon, S. (1956). The Lonely Londoners. St. Martin's Press.

Soyer, G. (2019). Urie Bronfenbrenner: The Ecology of Human Development Book Review. Journal of Culture and Values in Education,2(2), 77-80. https://doi.org/10.46303/jcve.02.02.6

Tolba, N. (2018). From Rebellion to Riots. Research in Social Sciences and Technology, 3(2), 93-114. https://doi.org/10.46303/ressat.03.02.6

Ugurlu, O. (2014). Identity formation and community organization among Kurdish diaspora in London. Journal of Ethnic and Cultural Studies, 1(1), 22-34.

Walcott, D. (2007). Selected poems. Farrar, Straus, \& Giroux.

Wambu, O. (2011, March 3). Black British literature since Windrush. BBC. http://www.bbc.co.uk/history/british/modern/literature_01.shtml.

Webster, W. (2018, April 18). Windrush generation: The history of unbelonging. The Conversation. https://theconversation.com/windrush-generation-the-history-ofunbelonging-95021

\section{Notes on Contributor}

Nayera M. Hassan is an assistant professor of English Literature in the English department, College of Arts, Minia University, Egypt. Presently, she works at Jouf University, Saudia Arabia. Receiving her Bachelor's degree in 1998, she has been appointed as a demonstrator. She has got her MA in 2005, then a PhD in 2011. She has published a paper titled "A Prescription for Dislocation at the Time of Globalization: A Study of Caryl Phillips' Crossing the River" in a refereed journal. She holds an interest in dealing with YA fiction and the contemporary problems related to minorities and ethnicities. 